薬 物

急性副鼻腔炎に対するアジスロマイシンの臨床効果

一投与方法による臨床効果の差はあるか一

深澤啓二郎1) ・高安 定1) ・橋本 喜輝1) 藤井 恵美 ${ }^{2}$

奥中美恵子'2) ・岩田 彩子3) $・$ 阪上 雅史 ${ }^{11}$

\title{
A Clinical Study of Azithromycin Hydrate for Acute Sinusitis with Special Regard to Methods of Oral Administration
}

\author{
Keijiro Fukazawa, Sadamu Takayasu, Yoshiteru Hashimoto and Masafumi Sakagami \\ (Hyogo College of Medicine) \\ Megumi Fujii and Mieko Okunaka \\ (Meiwa Hospital) \\ Ayako Iwata \\ (Amagasaki Central Hospital)
}

\begin{abstract}
Azithromycin hydrate (AZM) is a new macrolide antimicrobial. In this study, we evaluated the clinical efficacy of AZM for acute sinusitis. The patients were randomly divided into two groups. Twenty-five patients (Group A) were given a daily 500-mg oral dose of AZM for 3 days, and 26 patients (Group B) were given the same dose of AZM two times with a 1-week interval. The clinical efficacy rate was $85.2 \%$ in Group A and $88 \%$ in Group B, and there was no significant difference in the efficacy rates between these groups. These findings suggested that AZM was useful for the treatment of acute sinusitis and that a 500 $\mathrm{mg}$ oral dose of AZM for 3 days should be sufficient.
\end{abstract}

Key words : Azithromycin, acute sinusitis, oral administration, bacterial study

はじめに

アジスロマイシン $(\mathrm{AZM})$ は 2000 年に国内で販売開 始された 15 員環マクロライド系抗生剤である.AZM は 経口投与後, 食細胞内のライソゾームに取り込まれたの ち高濃度に濃縮され, 病巣部で細菌を領食する際により 有効に殺菌作用を働かせることが特徵とされる112). また 組織内へ非常に高い濃度で移行し3), 容易に代謝されな
いため長期間持続するといわれており投与方法は 3 日間 と限定されている. 本剤販売開始後, 本邦における耳鼻 咽喉科領域での AZM の臨床効果についての検討は十分 とはいえず，われわれの渉猟し得た急性副鼻腔炎を対象 とした検討は坂本 ${ }^{4)}$, 馬場ら ${ }^{5)}$ の報告がみられるのみで あった。 今回, 急性副鼻腔炎例を対象に AZM の臨床効 果を判定した。 また，3日間のみの投与方法で十分な臨

1）兵庫医科大学耳鼻咽喉科学教室

2) 明和病院耳鼻咽喉科

3）尼崎中央病院耳鼻咽喉科 
床効果が得られるものかを検討する目的で，3 日間投与 1 回のみと 1 週間の間隔をあけて 2 回投与する方法につ いても比較検討した.

\section{対象と方法}

平成 13 年 10 月 1 日から同 15 年 11 月 30 日までの 2 年 2 力月間のうち, 兵庫医科大学耳鼻咽喉科, 尼崎中央病院 耳鼻咽喉科, 明和病院耳鼻咽喉科を受診した急性副鼻腔 炎例を対象とした。対象症例は 16 歳以上とし，受診前 2 週間以内に抗生剤の投与を受けていない症例とした。 た，基礎疾患を有するなど本剤の投与が不適と判断した 症例む除外した．症例をランダムに 2 群に分けた。 AZM $500 \mathrm{mg}(250 \mathrm{mg}$ 錠 2 錠) を 1 日 1 回 3 日間投与した群 (Group A), AZM の初回投与の 7 日後（1 週間目）から 再度 AZM（1 日 $500 \mathrm{mg}$ ) 3 日間投与した群 (Group B) で ある. 治療勃果の判定は, 臨床薬物治療学大系・臨床薬 効評価・耳鼻咽喉科領域抗菌薬薬効判定基準6) に準じて, 自覚症状 (鼻漏, 後鼻漏, 鼻閉, 頭重・頭痛) および鼻 内所見 (鼻粘膜の発赤, 鼻粘膜の浮腫・腫脹, 鼻汁量, 鼻汁性状, 後鼻漏量) を 4 段階に評価し臨床効果を判定 した. また鼻 X 線検査についても薬効効果判定基準 ${ }^{6}$ に 従い初診時と 2 週間後経過時点で行い罹患洞の陰影を評 価し改善度を判定した。併用薬剤は，抗生剂以外は投与 可能とし，ネブライザー療法も可能とした。自覚症状・ 所見・鼻 X 線による重症度を規定し，臨床効果を判定し た (表 1). 細菌学的検討では初診時および 2 週間経過時 点で中鼻道からの分泌物を採取し，細菌学的検討（(株） 三菱化学 BCL 一依頼）を行い，原因菌・AZM に対する 耐性（Resistant, Intermediate, Sensitive の 3 項目）およ び推定起炎菌の消長について検討した。

\section{結 果}

AZM 1 回投与群 (Group A, 25 例) と 2 回投与群 (Group B，26 例）の患者背景を示す (表 2). Group A がやや若年 の傾向にあったが，急性副鼻腔炎重症度で両者に有意差 を認めなかった (Mann-Whitney 検定).

全般有効率では, Group A で有効以上が 85.2\%, Group B では $88 \%$ とかなり高い有用性を示し，両群の間に有効 性に関する有意差は認めなかった（Mann-Whitney 検定） (図 1).

初診時に検出された細菌学的検査 (51 例) では, Streptococcus pneumoniae が多かったが, 20 例 (39.2\%) で細菌
表 1 副鼻腔炎における抗菌薬の効果判定基準

1. 各症状の推移の判定区分

投与前と投与終了時のスコアをもとに, 次のように各 症状の推移を判定する。

消失 : $3 \rightarrow 0,2 \rightarrow 0,1 \rightarrow 0$

改善 : $3 \rightarrow 1,3 \rightarrow 2,2 \rightarrow 1$

不変 : $3 \rightarrow 3,2 \rightarrow 2,1 \rightarrow 1$

悪化 : $2 \rightarrow 3,1 \rightarrow 2,1 \rightarrow 3,0 \rightarrow 1,0 \rightarrow 2,0 \rightarrow 3$

2. 自覚症状䇽よび他覚所見の改善度

各症状の推移をもとに投与終了時に自覚症状改善度 および他覚所見改善度をそれぞれ判定する。

著明改善: 有症状項目の $2 / 3$ 以上が消失し，他の項目 すべて改善を示したもの.

改善:有症状項目の $2 / 3$ 以上が消失または改善 し，かつ上記の“著明改善”の規定にあわ ないもの.

ただし，有症状項目が 1 項目の場合は，2 段階以上改善したものとする。

軽度改善 : 有症状項目の $2 / 3$ 未満が消失または改善 したもの.

不＼cjkstart変：すべての項目において消失，改善を認めな かったもの.

〈付則〉有症状項目のうち 1 項目でも悪化している場 合は不変とする。

3. 臨床効果

臨床効果の判定は, 自覚症状改善度および他覚所見改 善度より下図のように判定する。

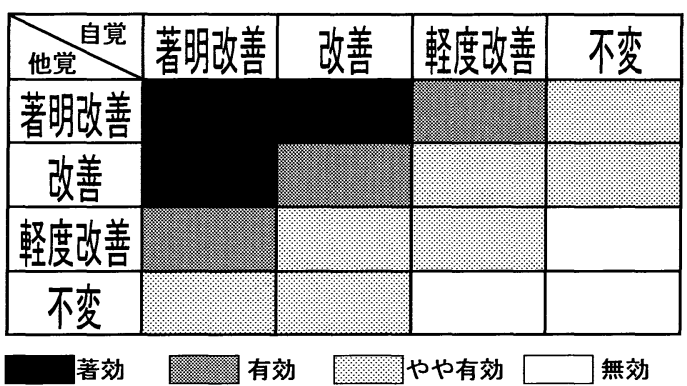

表 2 患者背景

\begin{tabular}{lcc}
\hline & Group A & Group B \\
\hline 症例数 & 25 & 26 \\
性別 (男 / 女) & $10 / 15$ & $14 / 12$ \\
年齢 (歳) & $36.2(19 \sim 68)$ & $43.6(21 \sim 74)$ \\
重症度 & & \\
重症 & 0 & 0 \\
中等症 & 18 & 22 \\
軽症 & 7 & 4
\end{tabular}

が検出できなかった（表 3). 投与前に菌が検出され，投 与後 (2 週間後) での細菌検查可能であった 26 例のうち, 


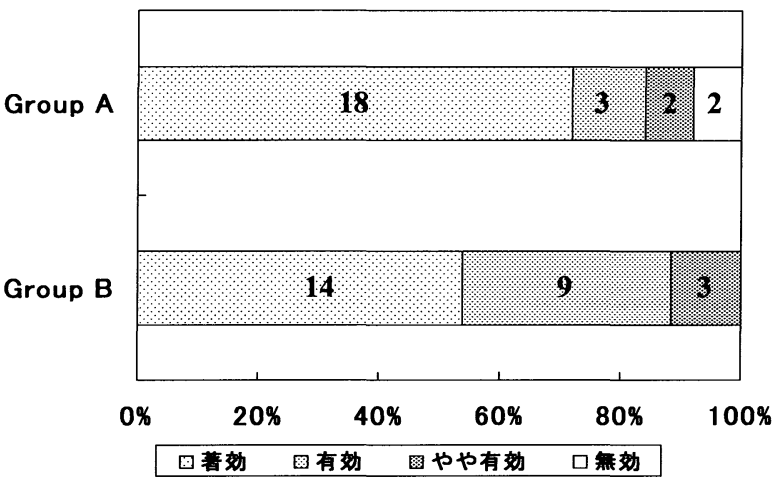

図 1 有効率の比較

両者に有意差は認めない（Mann-Whitney 検定).

表 3 初診時細菌学的検查結果

\begin{tabular}{lccc}
\hline \hline & Group A & Group B & 計 \\
\hline St. Pneumoniae & $4^{*}$ & $6^{* *}$ & 10 \\
H. Influenzae & $3(4)$ & $2(3)$ & $5(7)$ \\
M. Catarrharis & 1 & 1 & 2 \\
St. Aureus & $3(4)$ & $2^{* * *}$ & $5(4)$ \\
Coagulase negative & $3^{* * * *}$ & 2 & 5 \\
$\quad$ Staphylococci & 1 & 0 & 1 \\
Enterobacter & 0 & 2 & 2 \\
Corynebacterium & 0 & 1 & 1 \\
E. Coli & 10 & 10 & 20 \\
Negative & & &
\end{tabular}

* PRSP 1 例, PISP 2 例含む, ** PISP 2 例含む, *** MRSA 1 例含む, **** $\beta$-lactamase (+) 1 例含む.（）内は複数 検出菌を認めた例数を示す.

21 例（80.8\%）で菌消失であり，4例で菌交代を生じ， 1 例で菌不変であった.AZM に対する耐性を有する菌は 13 例にみられた。 その内訳は Streptococcus pneumoniae が 8 例（PRSP 1 例，PISP 3 例含む) で, Coagulase negative Staphylococci が 2 例 ( $\beta$-lactamase (+) 1 例含む), MRSA 1 例, Enterobacter aerogenes 1 例, E. coli 1 例であった. こ の 13 例の 2 週間後の細菌検查では Coagulase negative Staphylococci 検出例のみ菌不変であり, そのほかはすべて 菌消失であった。

初診時，鼻 X 線による罹患洞では 45 例が上顎洞，36 例が節骨洞（重複含む）であった．鼻 X 線による AZM 投与前後の評価が可能であったのはGroup A 17例, Group B 19 例で, 両群の鼻 X 線による陰影改善度に有意差は認 めなかった（Mann-Whitney 検定）（図 2).

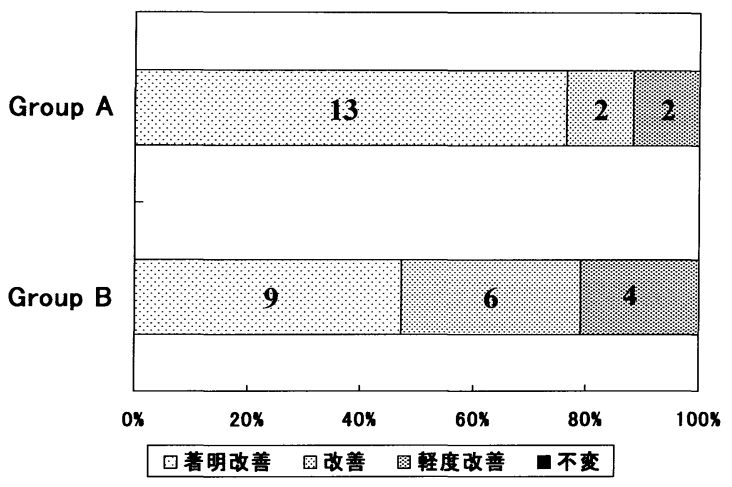

図 2 鼻 X 線所見改善度の比較 両者に有意差を認めない（Mann-Whitney 検定）.

AZM 併用薬剤は, Group A でカルボシステインが 15 例 に, ベタメタゾン・d- マレイン酸クロルフェニラミンが 10 例（重複含む）に投与され，Group B ではカルボシス テインが 19 例に, ベタメタゾン・d- マレイン酸クロル フェニラミンが 12 例（重複含む）に投与されていた. 上 㴿洞穿刺を行った症例はみられなかった。

なお，今回の検討中に副作用などの有害事象の発生は みられなかった．実際の症例を供覧する。

症例 $1: 26$ 歳女性. 10 日前に感冒様症状あるも特に治 療せず， 3 日前から膿性鼻漏が出現，1日前から頭痛もみ られたため兵庫医科大学耳鼻咽喉科を受診した。家族歴, 既往歷に特記すべきことはない. 初診時鼻内所見では, 右中鼻道に膿性分泌物を認め鼻粘膜は中程度腫脹し，左 鼻内には少量の粘性分泌物を認めた。鼻単純 X 線では, 右上顎洞に中程度陰影, 左上顎洞に軽度陰影を認めた (図 3 左). 急性副鼻腔炎と診断し, 初診時汃ら AZM 1 日 1 回 $500 \mathrm{mg}$ を 3 日間, カルボシステイン $1500 \mathrm{mg} 1$ 日 3 回 2 週間経口投与した. 2 週間後の鼻内所見は, 両側鼻汁は 消失し，鼻粘膜腫脹も軽快していた。 また 2 週間後の鼻 $\mathrm{X}$ 線所見では両側上顎洞陰影は消失していた (図 3 右)。初 診時に行った細菌学的検査では, Penicillin-resistant Streptococcus pneumoniae（PRSP）（AZM resistant）を認め たが，2 週間後の右中鼻道粘液の細菌検查では菌消失で あった。

症例 $2: 70$ 歳男性. 2 週間前から両側粘性鼻漏が出現 し徐々に増覀傾向にあり後鼻漏も自覚するようになった ため, 兵庫医科大学耳鼻咽喉科を受診した. 家族歷, 既 往歴に特記すべきことはない. 初診時鼻内所見では, 両 側中鼻道に膿粘性分泌物を認め, 鼻単純 X 線では両側上 


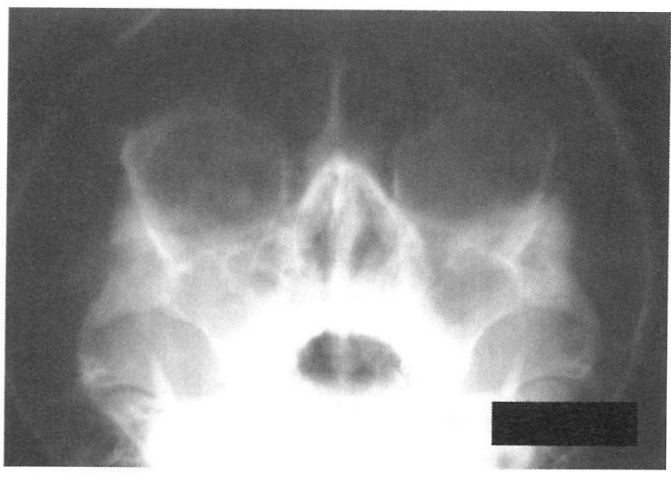

投与前

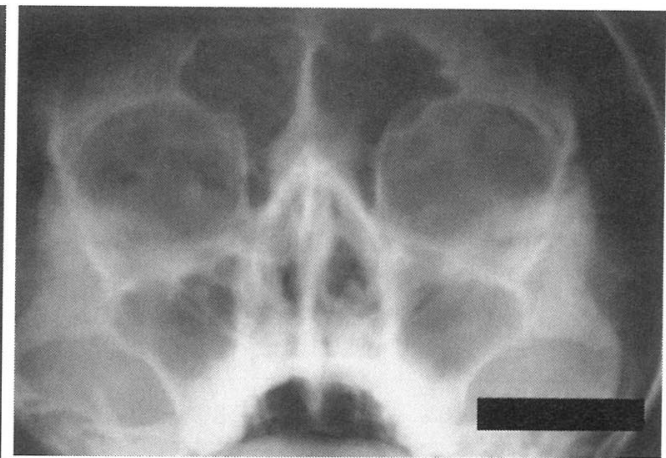

投与後

図 3 症例 1.26 歳女性. 鼻 X 線所見

両側上顎洞陰影は著明に改善している.
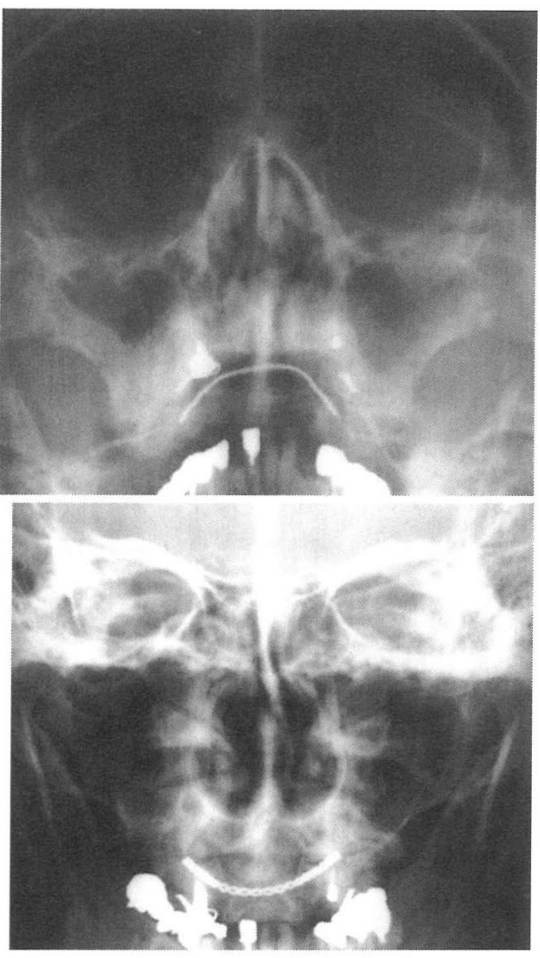

投与前
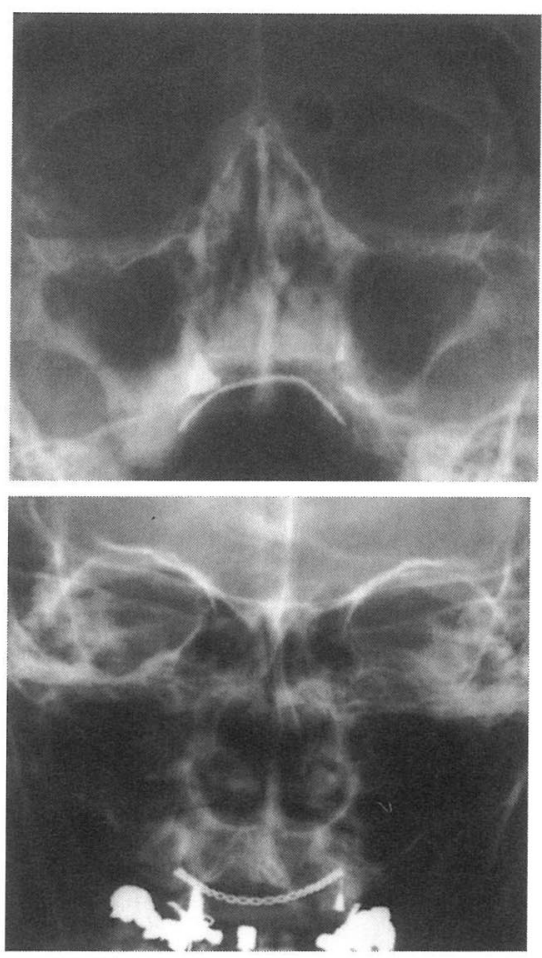

投与後

図 4 症例 2. 70 歳男性. 鼻 X 線所見 両側上顎洞, 篩骨洞の陰影が著明に改善している.

顎洞・篩骨洞に中程度陰影を認めた (図 4 左)。両側急性 副鼻腔炎と診断し, 初診時加ら, AZM $500 \mathrm{mg}$ を 1 日 1 回 3 日間投与し,さらに 1 週間後同量の AZM を経口投与し た。なお，初診時からカルボシステイン $1500 \mathrm{mg}$ を1日 3 回 2 週間経口投与した. 2 週間後の鼻内所見では, 両側
鼻汁を認めず自覚症状も消失していた。 2 週間後の鼻X 線ではすべての副鼻腔で陰影が消失していた（図 4右). 初診時の中鼻道分泌物の細菌検查では, Moraxella catarrharis $\beta$-lactamase（+）（AZM sensitive）が検出され たが，2 週間後の検查では，菌消失であった。 


\section{考察}

AZM は経口投与後, 腸管から吸収されたのち, 食細 胞・マクロファージに取り込まれ細胞質内のライソゾー ム中に高濃度に蓄えられる. その後病変部に誘導された 食細胞・マクロファージが細菌を貪食する際に, 局所に おいてより有効に細菌に対して効果を示すとされる。 た組織内の半減期が長く短期間での投与で有効な効果が 期待できる1) 3). 本研究において中鼻道からの検出菌 は, Streptococcus pneumoniae, Haemophilus influenzae, Moraxella catarrhalis が多く, 従来の報告 ${ }^{47)}$ ) と同様の傾 向であった. 今回 51 例中 13 例 $(25.5 \%)$ に AZM 耐性 菌がみられ，多くは Streptococcus pneumoniae であった (13 例中 8 例 $(61.5 \%))$. しかし AZM 耐性を示した細菌 に対する効果は高く（13 例中 12 例で菌消失）, PRSP • PISP 検出例全例に対しても有効であった（症例 1). これ は in vitro で耐性を示していても，AZM が感染病巣で高 濃度に作用したことを示すものと考える．Karma ら ${ }^{3)}$ は AZM $500 \mathrm{mg}$ の単回投与でも上顎洞粘膜において長期間 にわたり AZM 濃度を維持するとしている. 症例 2 では Moraxella catarrharis $\beta$-lactamase（十）であったが, AZM に対しては感受性があり早期に症状の軽快をみた。

マクロライド系抗菌剤は, 副鼻腔炎治療として少量長 期投与が行われているが，マクロライド系抗菌剂に対す る耐性を有する Streptococcus pneumoniae の遺伝子変異の 研究も進められている ${ }^{8)}$. 急性中耳炎罹患児での報告で はあるが，上咽頭からの Streptococcus pneumoniae の約 70 $\%$ に薬剤耐性に関する遺伝子（mefE， ermAM 遺伝子） が発現しているとの報告がある ${ }^{9)}$. AZM はマクロライド 系抗菌剤に分類されるが, AZM は組織でのマクロファー ジなどによる高濃度の薬剤暴露を細菌に対して行えるた め耐性菌に対する有用性も高いのではないかと考える.

AZM 1 回投与群 $(500 \mathrm{mg} \times 3$ 日) と 2 回投与群 $(500 \mathrm{mg} \times$ 3 日× 1 回）の臨床効果を比較検討したが， 1 回投与群 (Group A） で 85.2\%，2 回投与群（Group B） で 88\%の 症例に有用であり，両群間に有効率の有意差は認めな かった. これらの有効率は, 坂本 ${ }^{4)}$, 馬場ら ${ }^{5)}$ の報告と ほぼ同様な成績であった。臨床薬物治療学大系・臨床薬 効評価 ${ }^{6)}$ では，抗生剂単独投与での検討が推奨されてい るが，なるべく早期の症状緩和を考慮し，本研究では他 の抗生剂以外の併用薬剤の規制を行わなかった. ただし， 1 回投与群（Group A）と 2 回投与群（Group B）間に併 用薬剤使用に大きな差はなかったと考えている.
本研究のように, 異なる AZM 投与方法の治療成績に ついての報告は今までなく, 一般臨床医にとって, AZM が 3 日間のみの投与ではたして有効なのかと危惧される 場合もあろうかと思われるが，今回の急性副鼻腔炎に対 する臨床効果においては 1 回（3 日間）の投与で十分な 効果を認めており, AZM の使用方法としては現行の使用 方法でよいと思われた。今回の対象症例のほとんどは初 診時以降 1 週間, 2 週間のみの来院で経過観察しており, 本薬剤による患者の通院負担も軽減する可能性もあると 思われた。

急性副鼻腔炎に対して第一選択剤としてペニシリン系 薬剤が推奨される10).ところが Streptococcus pneumoniae では PR (I) SP の検出頻度が増加しており7), Haemophilus influenzae で \& $\beta$-lactamase non-producing Haemophilus influenzae (BLNAR) が問題となっている. いままでの抗 生剂の選択・使用方法を十分反省する必要があると考え るが，ペニシリン無効例などの成人の急性副鼻腔炎に対 する治療薬の一つとしてAZM の有用性が期待できると 思われる。

\section{まとめ}

急性副鼻腔炎に対する AZM の臨床効果を検討した. 3 日間 1 回投与群と 3 日間 2 回投与（1 週間の間隔をあけ る）群では，有効率に有意差がなく，1 回投与で十分な 臨床効果が得られた。 また, AZM 而性であった菌に対し ても有効であったことは, AZM の病巣への移行が優れて いることを示唆するものと考えられ，成人の急性副鼻腔 炎に対して有用であった。

\section{参考文献}

1) Founds G, Shepard RM and Johnson RB : The pharmacokinetics of azithromycin in human serum and tissue. J Antimicrob Chemother 25 Suppl A : 73 82, 1990.

2) Baldwin DR, Wise R, Andrews JM, et al. : Azithromycin concentrations at the sites of pulmonary infection. Eur Respiv $\mathrm{J}$ $3: 886 \sim 890,1990$.

3) Karma P, Pukander J and Penttila M : Azithromycin concentrations in sunus fluid and mucosa after oral administration. Eur J Clin Microbiol Infect Dis $10: 856 \sim 589,1991$.

4）坂本 徹：急性副鼻腔炎に対するアジスロマイシンの臨床 効果. 感染と抗菌薬 $6: 227 \sim 232,2003$.

5）馬場駿吉, 宮本直哉, 海野徳二, 他：耳鼻咽喉科領域感染 症に対する Azithromycin の基礎的ならびに臨床的検討. 耳 
鼻 $41: 946 \sim 963,1995$.

6）馬場駿吉 : 4 臨床薬効評価. 臨床薬物治療学大系（中島光 好編). $320 \sim 332$ 頁, 株式会社情報開発研究所, 東京, 1987 .

7）馬場駿吉, 高坂知節，市川銀一郎，他：第 2 回耳鼻咽喉科 領域感染症臨床分離菌全国サーベイランス結果報告. 日耳 鼻感染誌 $18: 48 \sim 63,2000$.

8）紺野昌俊, 生方公子： $\beta$ - ラクタム系薬とマクロライド系薬 耐性機構. 改訂一ペニシリン耐性肺炎球菌. $108 \sim 110$ 頁, 協和企画通信, 東京, 1999 .

9）山中 昇：耳鼻咽喉科感染症におけるガイドライン (1) 総
論. 化学療法の領域 $18: 62 \sim 68,2002$.

10）原㴊保明, 林 達哉：耳鼻咽喉科感染症におけるガイドラ イン（3）諸外国におけるガイドライン。化学療法の領域 $18: 80 \sim 94,2002$.

原稿受付：平成 16 年 3 月 2 日

原稿採択：平成 16 年 4 月 30 日

別刷請求先 : 深澤啓二郎

干663-8501 西宮市武庫川町1-1 兵庫医科大学耳鼻咽喉科学教室 